


\section{Th1s report was prepared as an account of Government sponsored work. Nelther the United}

States, nor the Commisaion, nor any person acting on behalf of the Commission:

A. Makes any warranty or representation, expressed or implied, wh thespect to the accuracy, completeness, or usefulness of the Information contained in this report, or that the use of any information, apparatus, method, or process disclosed in this report may not infringe privately owned rights; or

B. Aseumes any liabilities with respect to the use of, or for damages resulting from the use of any information, apparatus, method, or process disclosed in this report.

As used in the above, "person acting on behalf of the Commission" includes any employee or contractor of the Commission, or employee of such contractor, to the extent that such employee or contractor of the Commission, or employee of such contractor prepares, disseminates, or provides access to, any information pursuant to his employment or contract with the Commission, or his employment with such contractor.

Printed in USA. Price $\$ 1.00$

Avallable from the Clearinghouse for Federal Sclentif-1c and Technical Information, National Bureau of Standards,

U. S. Department of Commerce, Springfield, Virginia 
Reactor Technology (TID-4500, 43rd Ed.)

\title{
RADIOLYSIS OF ION EXCHANGE RESINS USED IN THE PURIFICATION SYSTEMS OF SAVANNAH RIVER REACTORS
}

\author{
by
}

Elizabeth W. Baumann

Approved by

E. I. Albenesius, Research Manager Analytical Chemistry Division

July 1965

\author{
E. I. DU PONT DE NEMOURS \& COMPANY \\ SAVANNAH RIVER LABORATORY \\ AIKEN, SOUTH CAROLINA \\ CONTRACT AT(07.2)-1 WITH THE \\ UNITED STATES ATOMIC ENERGY COMMISSION
}




\section{ABSTRACT}

Loss of Ion exchange capacity and the presence of watersoluble materials in depleted delonizer resin from a Savannah River Plant reactor system indicated the resins were degraded during service. Calculations and on-line measurements of radiation dose showed that the threshold dose for resin damage, $10^{7} \mathrm{rad}$, was approached or exceeded in the deiontzer beds. Sodium-24, produced by the $(n, \alpha)$ reaction on aluminum fuel cladding, was the major contributor to the radiation dose. 


\section{CONTENTS}

Page

List of Tables and Figures 4

Introduction $\quad 5$

$\begin{array}{ll}\text { Summary } & 6\end{array}$

$\begin{array}{ll}\text { Discussion } & 7\end{array}$

Conditions of Resin Service $\quad 7$

$\begin{array}{ll}\text { Investigation } & 7\end{array}$

Calculated Estimate of Dose 8

Measurement of On-Iine Dose Rate 9

Examination of Water from Deionizers 10

Examination of Depleted Deionizer Resin. 12

Conclusions ' 13

$\begin{array}{ll}\text { Acknowledgment } & 13\end{array}$

$\begin{array}{ll}\text { References } & 14\end{array}$

Appendix - Method of Calculation of Dose to Deionizer Resin During Service $\quad 15$ 


\section{LIST OF TABLES AND FIGURES}

$\begin{array}{clc}\text { Table } & \frac{\text { Page }}{\text { I }} & 8 \\ \text { II } & \text { Process to Resin from Selected Radionuclides } & 8 \\ \text { III } & \text { Values Used in Dose Rate Calculations } & 10\end{array}$

\section{Figure}

1 Depletion of Resins on Gamma Irradiation 8

2 On-Line Dose Rate Measurements on Mixed-Bed Delonizers

$3 \mathrm{D}_{2} \mathrm{O}$ from Depleted Delonlzers $\quad 11$

4 Radiolytic Depletion of Plant Deionizer 12 


\title{
RADIOLYSIS OF ION EXCHANGE RESINS USED IN THE PURIFICATION SYSTEMS OF SAVANNAH RIVER REACTORS
}

\author{
INTRODUCTION
}

Ion exchange resins are commonly used to purlfy water, but when the resin itself is exposed to degradative conditions, the resin may contribute impurities as well as remove them. In purification of coolant water from nuclear reactors, induced activities can arise from degradation products of the resin and can contribute to problems with radioactivity in the reactor complex. In addition, impurities released into the water can alter the solution composition which must be carefully controlled to reduce metal corrosion and radiolytic decomposition of the water. The radiolytic and oxidizing environment within the resin bed, from bulldup of radioactive materlals there, is conduclve to resin degradation.

At Savannah River, impurities contributed from the Ion exchange resins became apparent when ${ }^{35} \mathrm{~S}$ and sulfate ion were found in the $\mathrm{D}_{2} \mathrm{O}$ coolant-moderator and ${ }^{32} \mathrm{P}$ was found on surfaces of the aluminum-clad fuel elements. These impurities were traced to the beds of cation exchange resin (sulfonic acid type) that were used to supplement and conserve the mixed anion-cation beds in the purification of the moderator, which is maintained slightly acid to reduce corrosion of aluminum fuel cladding. The ${ }^{35} \mathrm{~S}$ and ${ }^{32} \mathrm{P}$ were attributed to neutron activation of natural sulfur released from the cation resin beds. Use of cation resin beds has since been discontinued.

Other conditions in the reactor were also attributed to degradation of delonizer regins: (1) the prevalence of $\mathrm{CO}_{2}$ in the reactor system, from oxidation of organic material derived from the resin beds, and (2) a calculated utilization that was unusually low for mixed-bed deionizers. The low utilization suggested that exchange capacity was being exhausted by a mechanism other than removal of ions from the moderator.

The present work was done to assess the extent and the effects of radiation damage to the deionizer resins in SRP reactor systems. Although the emphasis in this work was on radiolytic degradation, the oxidizing environment that results from low concentrations of peroxide and nitric acid in the moderator also promotes degradation of resin. (1) Thermal degradation was judged unlikely in this flowing system of cooled $\mathrm{D}_{2} \mathrm{O}$. 


\section{SUMMARY}

Phenomena attributed to degradation of delonizer resins during service in the Savannah River reactor systems prompted an investigation to confirm that degradation occurs and to determine the cause. Measurements and calculation of radiation dose to the resins, determination of the amount and composition of water-soluble material from depleted resin beds, and examination of depleted delonizer resin demonstrated that resin degradation occurs and that the major cause is probably the radiation dose the resins recelve during service. Radiation doses approach or exceed a threshold dose $\left(10^{7} \mathrm{rad}\right)$ at which perceptible damage occurs. Radiation doses of this magnitude are attalned in this particular system because of relatively high concentrations of ${ }^{24} \mathrm{Na}$, a radiolsotope produced by the $(n, \alpha)$ reaction on aluminum fuel cladding.

Although radiation damage in SRP delonizer resins may result in depletion of as much as $30 \%$ of the inftial exchange capac1ty, a satisfactory service life of 3 to 4 months is practical and pollution of the moderator with resin degradation products does not occur when mixed bed resins are used. 


\section{DISCUSSION}

\section{CONDITIONS OF RESIN SERVICE}

In the recirculating coolant-moderator system(2) of the SRP reactors, a bypass stream of moderator $\left(D_{2} O\right)$ is filtered and delonized by one or more parallel purification cells that consist of $25 \mathrm{ft}^{3}$ of resin flanked upstream and downstream by asbestos leaf-type fllters. The mixed-bed delonizers contain a mixture in the ratio of one exchange equivalent of "Amberlite"* IR-120-D to two exchange equivalents of "Amberlite" IRA-400-OD. Beds of "Amberl1te" IR-120-D alone have also been used for brief periods on a test basis.

The rate of downward flow through a deionizer is 20 to 80 gallons per minute. Each mixed-bed delonizer processes 3 to 6 million galions during on-line service of three to four months. More than $90 \%$ of the radioactivity is removed from the moderator as it passes through the deionizer.

The radioactivity comprises both fission products and neutron activation products. (3)

\section{INVESTIGATION}

The invertigation encompassed four steps. Radiolytic environment in the delonizers was investigated by

- Calculation of the radiation dose to the deionizers from retention of major known radionuclides

- Experimental corroboration of the dose through dose rate measurements on on-line delonizers

Degradation in resin beds was investigated by

- Analysis of water that had been in contact with depleted resins to determine water-soluble materials

- Analysis of resins from a depleted delonizer

* Trademark of Rohm and Haas Co., Philadelphia, Pa. 


\section{Calculated Estimate of Dose}

An estimate was made of the beta-gamma dose received by the deionizer resins from typical amounts of four prominent radionuclides found in the moderator: ${ }^{24} \mathrm{Na},{ }^{239} \mathrm{~Np},{ }^{56} \mathrm{Mn}$, and ${ }^{133} \mathrm{I}$. The calculated dose for normal service is given in Table $I$, with the source and typical concentration of each nuclide. Detalls of the calculations are glven in the Appendix.

\section{TABLE I}

Dose to Resin from selected Radionuclides

(calculated for normal service)

Typlcal Total Beta-Gamma Concentration, Dose Absorbed by

Nuclide Half-Life Mode of Formation $\mu \mathrm{c} / \mathrm{mI}$ Resin, rad/cc

$\begin{array}{ll}{ }^{24} \mathrm{Na} & 15 \mathrm{~h} \\ { }^{238} \mathrm{~Np} & 2.3 \mathrm{~d} \\ { }^{56} \mathrm{Mn} & 2.6 \mathrm{~h} \\ { }^{133} \mathrm{I} & 21 \mathrm{~h}\end{array}$

$21 \mathrm{~h}$

$$
\begin{gathered}
{ }^{27} \mathrm{AI}(n, \alpha) \\
23{ }^{8} \mathrm{U}(\mathrm{n}, \gamma)^{239} \mathrm{U}\left(-\beta^{-}\right) \\
{ }^{55} \operatorname{Mn}(n, \gamma)
\end{gathered}
$$

Fission product

$$
0.5
$$

0.5

0.05

$$
7 \times 10^{8}
$$$$
6 \times 10^{6}
$$$$
1 \times 10^{6}
$$

Total $\frac{1 \times 10^{5}}{1.4 \times 10^{7}}$

These results show that ${ }^{24} \mathrm{Na}$ is a major contributor to the dose and that the total predicted dose is greater than $10^{7}$ rad. The actual dose will be considerably higher than that calculated because shortlived nuclides were not included in the estimate. These nuclides will be abundant in the deionizer feed, which has less than five minutes decay time out of the reactor.

Comparison of the calculated dose with results from radiation damage studies $(4)$ (FIgure 1) shows that the dose to the resins in the delonizers is sufficlently high to cause a measurable decrease in useful exchange capacity.

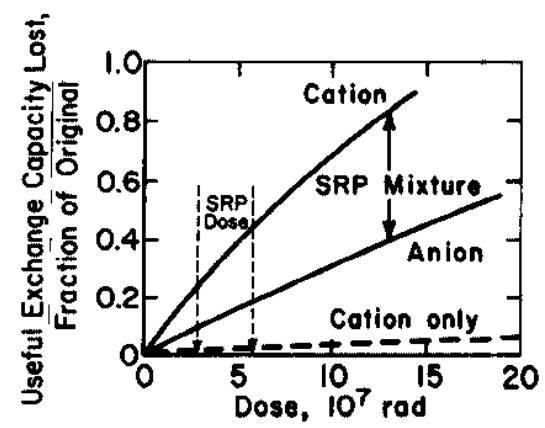

FIG. 1 DEPLETION OF RESINS ON GAMMA IRRADIATION 


\section{Meosurement of On-Line Dose Rote}

Measurements of gamma dose rate to the resins during delonizer operation were made with polyacrylamide dosimeters $(5)$ placed at intervals from top to bottom of the deionizers. One set of measurements was made with the dosimeters outside the deionizer vessel. A second set was made with the dosimeters in a well within the deionizer. Measurements made on four delonizers are shown in Figure 2 to illustrate the range of dose rates encountered.

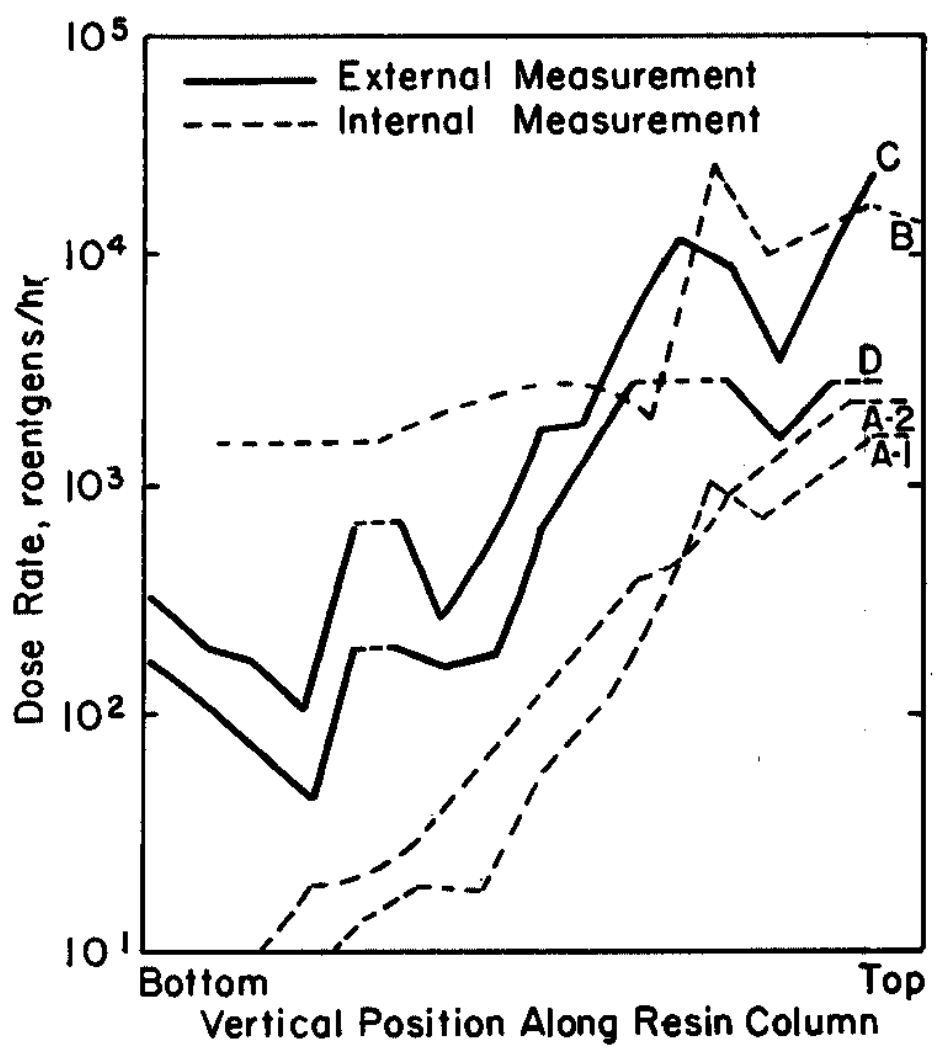

FIG. 2 ON-LINE DOSE RATE MEASUREMENTS ON MIXED-BED DEIONIZERS (Process varibles of deionizers ore given in Table II) 
Process variables that affect the dose rate are given in Table II for the deionizers examined. The instantaneous dose rate depends upon both the flow and the radioactivity of the feed. Also, dose rate is increased during service through accumulation of long-lived materials in the bed.

\section{TABLE II}

Process Varlables for Delonizens in Figure?

\begin{tabular}{|c|c|c|c|}
\hline Dosimeters Inside Vessel & $\begin{array}{c}\text { Throughput, } \\
10^{\circ} \mathrm{gal}\end{array}$ & $\begin{array}{l}\text { Flow, } \\
\text { gpm }\end{array}$ & $\begin{array}{l}\text { Relative } \\
\text { Activity } \\
\text { In Feed } \\
\end{array}$ \\
\hline $\begin{array}{l}\text { Deionizer A } \\
\frac{1}{2}\end{array}$ & $\begin{array}{l}0.23 \\
2.9\end{array}$ & $\begin{array}{l}25 \\
25\end{array}$ & $\begin{array}{l}1.0 \\
1.3\end{array}$ \\
\hline $\begin{array}{c}\text { Deionizer } B \\
\text { Dosimeters Outside Vesse] }\end{array}$ & 1.9 & 49 & 60 \\
\hline Deionizer C & 4.0 & 23 & 16 \\
\hline Deionizer D & 3.3 & 53 & 12 \\
\hline
\end{tabular}

The dose rate profile is affected by accumulation of ionic radionuclides and of solids that pass through the 10-micron prefilter. The ionic materials tend to concentrate initialfy at the top of the column and travel down the column in the normal pattern of ion exchanger depletion. The solids are distributed more or less uniformly throughout the bed.

In these measurements, the beta dose was shielded out by the walls of the deionizers and dosimeters, but it is estimated that the beta dose will be comparable to the gamma dose. At a service life of 100 days, the average beta-plus-gamma dose rate must exceed $10^{4} \mathrm{rad} / \mathrm{hr}$ before appreciable radiation damage is anticlpated (Figure 1 ).

The results of the measurements (Figure 2) show that the resin in the top half of Delonizers $B$ and $C$ attained a damaging dose. Deionizer $D$ was probably damaged only slightly, if at all. Slgnificant damage would not be expected in Delonizer $A$, where low flow rate and low activity feed combined to minimize the dose incurred.

\section{Examination of Water from Deionizers}

Release of dissolved material from the detonizers into the reactor system could not be confirmed directly through analysis of the delonizer effluent. The concentrations of total $C, S$, and $N$ were below the limits of detection of the analytical methods avallable. 
However, heavy water recovered from the depleted delonizers before they are discarded could be analyzed. This water had been in contact with resin for several months, and soluble materlal had concentrated in the aqueous phase. Aithough the analytical results of themselves could not indicate the amount of material the resins had released during service, potential release of soluble material from various types of deionizers with various service histories could be compared. Had a partially exhausted deionizer been placed back on-line after a period of stagnation, such soluble material could have entered the reactor system.

Analyses of water recovered from several depleted deionizers are plotted in Figure 3 with the total volume of water the delonizer had treated. Three types of depleted delonizers were examined: the conventional D-OD mixed beds, a mixed bed that was depleted by $\mathrm{CO}_{2}$ during service and was continued in use in the $\mathrm{D}-\mathrm{DCO}_{3}$ form, and cation resin beds originally in the $\mathrm{D}^{+}$form. The cation resin beds processed more water than did the mixed resin beds, and consequently they received the greater radiation dose. The cation beds released sulfur compounds, but these were retained more effectively by the mixed beds. With larger volumes treated, a tendency of the mixed beds to release sulfur compounds is discernible. The mixed bed that had treated the largest volume, and which was continued in use after conversion to the $\mathrm{D}-\mathrm{DCO}_{3}$ form, released as much sulfur as the cation resins. Between 60 and $70 \%$ of the sulfur was present as sulfate. In general the acidity and the amount of dissolved solids increased with sulfur concentration. The total nitrogen and carbon concentrations were below 5 and $100 \mathrm{ppm}$, respectively, the maximum sensitivities of the analytical methods used.

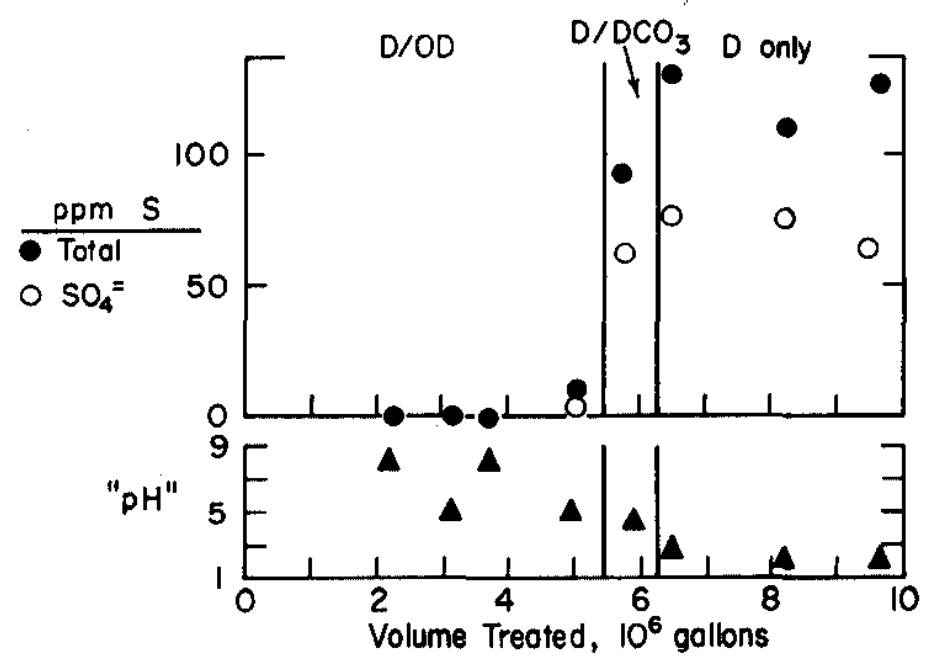

FIG. 3 D $D_{2} O$ FROM DEPLETED DEIONIZERS 
Examination of Depleted Deionizer Resin

Information about degradation of deionizer resins during actual Plant service was obtained through examination of resin from a depleted deionizer. Details of the examination are reported elsewhere. ( $\theta$ ) Cation and anion resin components were analyzed for exchange capacity and for degradation products absorbed. Sulfates and amines found in the resin were attributed to resin degradation.

The fraction of the original exchange capacity depleted through destruction of exchange sites and through absorption of degradation products is shown in Figure 4. Loss of exchange sites of the cation resin is high at the top of the bed, probably because of the high radiation dose that occurred from cationic radionuclides such as ${ }^{24} \mathrm{Na}$ that were concentrated there. Along the rest of the column, cation resin depletion was due principally to absorption of amines from the anion resin. The anion resin showed loss of exchange sites, as well as absorption of sulfate, throughout the column.
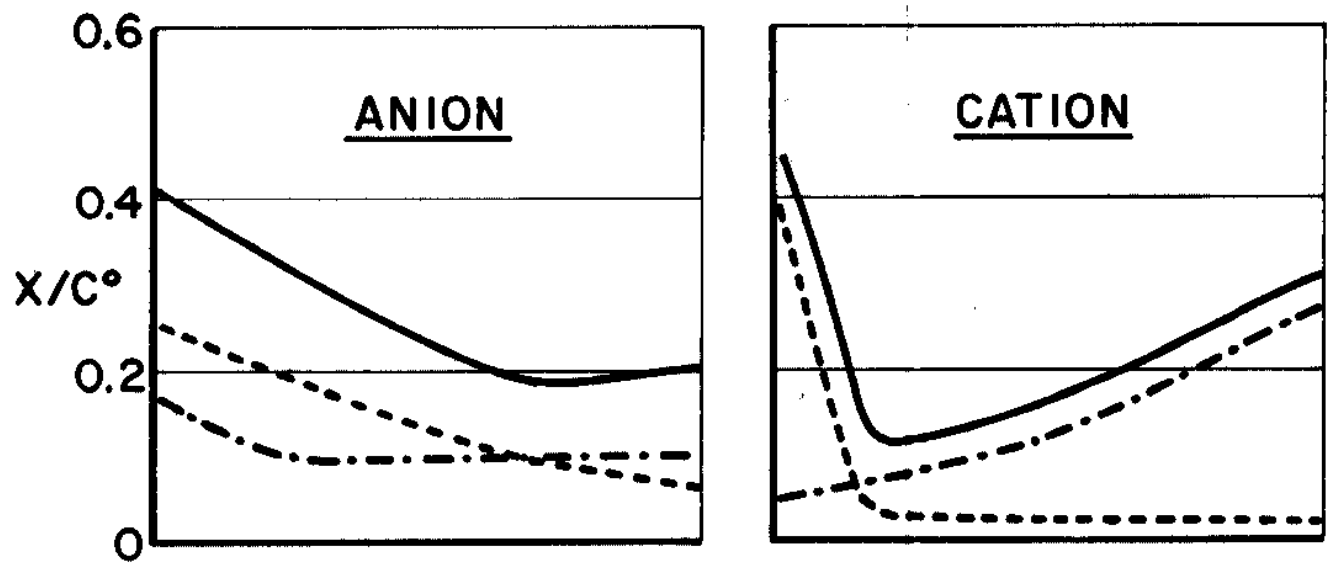

Top

Btm. Top

Bim.

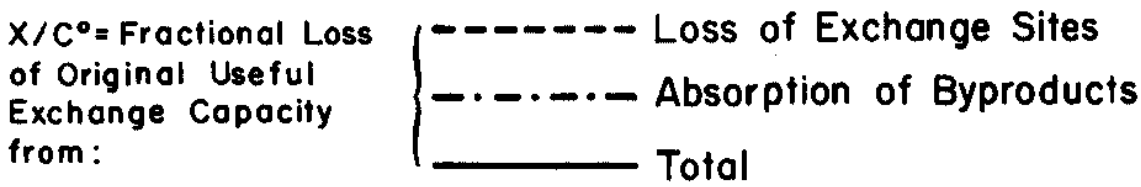

FIG. 4 RADIOLYTIC DEPLETION OF PLANT DEIONIZER 


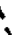

The average over-all total depletion due to radiolysis is in fair agreement with the estimates in Figure 1. Depletion of anion resin with sulfate is higher than predicted, and does not correspond well with the loss in exchange sites of the cation resin. Conditions of Plant service were not duplicated completely in the work reported by Figure 1. Nevertheless, occurrence of depletion due to degradation is confirmed and the magnitude of the effect is within the range of radiation damage proposed.

\section{CONCLUSIONS}

The long-term exposure to radioactivity inherent in reactor purification systems is conducive to radiation damage to the deionizer resins. For many reactor systems, the high threshold dose required $\left(10^{7} \mathrm{rad}\right)$ precludes perceptible radiation damage.

In the Savannah River reactors, however, two conditions contribute to attainment of sufficient dose for damage: a high neutron flux, which promotes production of induced activities, and the presence of aluminum, the precursor of ${ }^{24} \mathrm{Na}$, which makes a major contribution to the total dose.

Even when radiation damage occurs, a mixed-bed resin will not pollute the water significantly during normal use. Some exchange capacity is consumed by degradation products, and efficiency of utilization of the resin bed for water purification is thereby reduced.

Use of only cation or anion exchange resin for reactor coolant purification, rather than a combination of both, is inadvisable because resins in general will not retain their own degradation products, which will therefore be released to the system.

\section{ACKNOWLEDGMENT}

The contribution of the many people in the Works Technical Department of the Savannah River Plant, who made dose rate measurements and obtained samples of resin and water for examination, is gratefully acknowledged. The dose rate calculations were made by $\mathrm{D}$. H. Stoddard of the Savannah River Laboratory.

Information contained in this report was presented before the Division of Water and Waste Chemistry, 147th National Meeting of the American Chemical Society in Philadelphia, Pennsylvania, April 6, 1964. 


\section{REFERENCES}

1. L. F. Wirth, C. A. Feldt, and K. Odland, "Effects of Oxidants on Ion Exchangers." Ind. Eng. Chem. 53, 638-41 (1961).

2. G. N. Flannagan and R. F. Anderson, "Quality Control of Moderator In Savannah River Plant Reactors," paper presented at Symposium on Water Technology for Nuclear Applications at the 147th National Meeting of the American Chemical Society, Philadelphia, Pa., April 6, 1964.

3. F. B. Longtin. "Impurities in Moderator of Savannah River Plant Reactors," paper presented at Symposium on Water Technology for Nuclear Applications at the 147th National Meeting of the American Chemical Society, Philadelphia, Pa., April 6, 1964.

4. E. W. Baumann. "Gamma Irradiation of Mixed and Individual Ion Exchange Resins." (to be published).

5. A. I. Boni. "A Polyacrylamide Gamma Dosimeter." Radiation Research 14, 374-80 (1961).

6. E. W. Baumann. Depletion of Deionizer Resin in an SRP Reactor System. USAEC Report DP-973, E. I. du Pont de Nemours and Co., Savannah River Laboratory, Aiken, S. C. (1965). 


\section{APPENDIX \\ METHOD OF CALCULATION OF DOSE TO DEIONIZER RESIN DURING SERVICE}

\section{Conditions Assumed}

1. 100 days at $40 \mathrm{gpm}$

2. Dimensions of bed: $3 \mathrm{ft}$ diameter, $4 \mathrm{ft}$ high

3. Uniform contamination throughout bed

4. Contaminants in feed: ${ }^{24} \mathrm{Na},{ }^{239} \mathrm{~Np},{ }^{58} \mathrm{Mn}$, and ${ }^{133} \mathrm{I}$ at concentration shown in Table III

\section{TABLE III}

\section{Values Used in Dose Rate Calculations}

\begin{tabular}{|c|c|c|c|c|c|c|c|}
\hline Iuclide & $T_{\frac{1}{2}}$ & $\begin{array}{c}\text { Concentration } \\
\text { in Feed, } \\
\mu \mathrm{c} / \mathrm{ml}\end{array}$ & $\begin{array}{c}\overline{\mathrm{E}}_{\boldsymbol{\gamma}}, \\
\mathrm{Mev} / \mathrm{d} \\
\end{array}$ & $\begin{array}{l}\mu_{\mathrm{s}} \\
\mathrm{cm}^{-1} \\
\end{array}$ & $\begin{array}{l}\mu \mathrm{a}^{\prime} \\
\mathrm{cm}^{-1} \\
\end{array}$ & $\underline{B}$ & $\begin{array}{c}\overline{\mathrm{E}}_{\beta}, \\
\mathrm{Mev} / \mathrm{d} \\
\end{array}$ \\
\hline${ }^{24} \mathrm{Na}$ & $15 \mathrm{~h}$ & 0.5 & $2(a)$ & 0.05 & 0.033 & 3 & 0.55 \\
\hline $239 \mathrm{~Np}$ & $2.3 \mathrm{~d}$ & 0.5 & $0.2^{(b)}$ & 0.14 & 0.032 & 80 & 0.23 \\
\hline $56_{\mathrm{Mn}}$ & $2.6 \mathrm{~h}$ & 0.5 & $\left\{\begin{array}{l}0.84(c) \\
2\end{array}\right.$ & $\begin{array}{l}0.076 \\
0.048\end{array}$ & $\begin{array}{l}0.033 \\
0.027\end{array}$ & $\left.\begin{array}{l}9 \\
3\end{array}\right\}$ & 1.22 \\
\hline${ }^{133} \mathrm{I}$ & $2 I \mathrm{~h}$ & 0.05 & 0.59 & 0.1 & 0.034 & 18 & 0.51 \\
\hline
\end{tabular}

(a) There are two gamma photons per disintegration.

(b) Gamma energy is released at a rate of $0.124 \mathrm{Mev} / \mathrm{d}$.

(c) Two distinct gamma energles are assumed released; total gamma energy released per disintegration $=1.8 \mathrm{Mev} / \mathrm{d}$. 
If the nuclide is completely retained and uniformly distributed, the total activity per unit volume of resin at time $t$ is

$$
S_{v}=\frac{K}{\lambda}\left(1-e^{-\lambda t}\right)
$$

where $S_{V}=$ activity/cc

$\mathrm{K}=$ rate of accumulation on the resin, activity/cc/sec

$\lambda=$ the decay constant of the nuclide $=0.693 / \mathrm{T}_{\frac{1}{2}}, \mathrm{sec}^{-1}$

$t=$ the length of time the resin is used, seconds

As $t$ becomes very large relative to $\lambda$, the term $e^{-\lambda t}$ becomes insignificant, and the equilibrium activity on the resin is

$$
S_{v}(\text { equil })=\frac{K}{\lambda}
$$

Equilibrium activity is assumed for the nuclides considered in this calculation.

Gamma Dose

The gamma flux, at the center of the cylindrical container, is given by

$$
\phi=\frac{B S_{v}\left[G\left(\mu_{s} h b\right)\right]}{\mu_{s}}
$$

where $\phi=$ photons $/ \mathrm{cm}^{2} / \mathrm{sec}$

$B=$ buildup factor

$\mu_{s}=$ linear absorption cross section of the source material

$G\left(\mu_{S} h b\right)$ is a function of $\mu_{S}$, of $h$, the axial alstance to the center of the cylinder, and of $b$ which is equal to $\left(\mu_{s} R_{0}\right)$ where $R_{O}$ is the radius of the cylinder*.

* Derivation and detailed explanation are given in TID-7004, Reactor Shielding Design Manual. 
The rate of energy absorbed per gram (Mev/s/g) is

$$
R=\frac{\phi_{E} \mu_{A}}{\rho}
$$

where $\phi_{E}=$ the energy flux, the product of $\phi$ and energy per disintegration $\left(\mathrm{E}_{\gamma}\right), \mathrm{MeV} / \mathrm{cm}^{2} / \mathrm{sec}$

$$
\begin{aligned}
\mu_{A}= & \text { difference between total linear cross section and } \\
& \text { photon energy cross section for compton scattering } \\
\rho= & \text { density }(\mathrm{g} / \mathrm{cc}) \text {, assumed to be unity }
\end{aligned}
$$

The gamma dose (rad) to $I g$ or $I \mathrm{cc}$ of resin is given by

$$
\mathrm{D}_{\gamma}=\frac{\mathrm{Rt}}{\left(6.24 \times 10^{5} \mathrm{Mev} / \mathrm{erg}\right)(100 \mathrm{erg} / \mathrm{g} / \mathrm{rad})}
$$

Beta Dose

With the assumption that all beta energy is absorbed close to the source, the beta dose is given by

$$
D_{\beta}=\frac{S_{v} \bar{E}_{\beta} t}{\left(6.24 \times 10^{5} \text { Mev/erg }\right)(100 \mathrm{erg} / \mathrm{g} / \mathrm{rad})}
$$

where $\overline{\mathrm{E}}_{\beta}$ = average beta energy released per disintegration, Mev/d 